\title{
Adenoviral Gene Transfer of Interleukin 12 into Tumors Synergizes with Adoptive T Cell Therapy Both at the Induction and Effector Level
}

\author{
GUILLERMO MAZZOLINI, CHENG QIAN, IÑIGO NARVAIZA, MIGUEL BARAJAS, \\ FRANCISCO BORRÁS-CUESTA, XIAOMING XIE, MARINA DUARTE, \\ IGNACIO MELERO,* and JESÚS PRIETO*
}

\begin{abstract}
Tumors infected with a recombinant defective adenovirus expressing interleukin 12 (IL-12) undergo regression, associated with a cytotoxic $T$ lymphocyte (CTL)-mediated antitumor immune response. In the present study we generated anti-CT26 CTLs by short-term coculture of CT26 cells and lymph node cells obtained from mice harboring subcutaneous CT26 tumors injected with an adenoviral vector expressing IL-12 (AdCMVIL-12), control adenovirus (AdCMVlacZ), or saline. Regression of small intrahepatic CT26 tumors in unrelated syngeneic animals was achieved with CTLs derived from mice whose subcutaneous tumors had been injected with AdCMVIL-12 but not with CTLs from the other two control groups. The necessary and sufficient effector cell population for adoptive transfer consisted of $\mathrm{CDB}^{+} \mathrm{T}$ cells that showed anti-C T26 specificity partly directed against the AH1 epitope presented by $\mathrm{H}-2 \mathrm{~L}^{\mathrm{d}}$. Interestingly, treatment of a subcutaneous tumor nodule with AdCMVIL-12, combined with intravenous adoptive T cell therapy with short-term CTL cultures, had a marked synergistic effect against large, concomitant live tumors. Expression of IL-12 in the liver in the vicinity of the hepatic tumor nodules, owing to spillover of the vector into the systemic circulation, appeared to be involved in the increased in vivo antitumor activity of injected CTLs. In addition, adoptive $T$ cell therapy improved the outcome of tumor nodules transduced with suboptimal doses of AdCMVIL12. Our data provide evidence of a strong synergy between gene transfer of IL-12 and adoptive T cell therapy. This synergy operates both at the induction and effector phases of the CTL response, thus providing a rationale for combined therapeutic strategies for human malignancies.
\end{abstract}

\section{OVERVIEW SUMMARY}

Evidence that the IL-12 gene, transferred into tumors by adenovirus, displays antitumor activity is well confirmed, and this activity has been shown to involve immune and nonimmune mechanisms. IL-12 bioactivity results in a potent induction of tumor-specific CTLs that can be used for adoptive $T$ cell therapy. This study demonstrates that IL12 intratumor gene transfer and adoptive $T$ cell therapy are synergistic to the treatment of experimental transplantable colon cancer. Synergy includes not only the facilitation of CTL obtention but also mechanisms of cooperation at the effector phase of the combined therapy. This synergy seems to be highly beneficial in the treatment of established metastatic disease.

\section{INTRODUCTION}

\footnotetext{
A DOPTIVE CEllular THERAPy is defined as the infusion of immune effector cells for the treatment and/or prevention of a disease (Riddell and Greenberg, 1995; Yee et al., 1997). Different types of $\mathrm{T}$ cell populations have been used to treat viral infections and tumors in murine models (Kast et al., 1989; Lynch and Miller, 1991), leading to their use in the clinic (Riddell et al., 1992; Rossemberg et al., 1994; Henslop et al., 1996).
} 
A major hurdle for the feasibility of $\mathrm{T}$ cell adoptive therapy in oncology is the availability of tumor-specific $\mathrm{T}$ cells for in vitro expansion and differentiation into effector populations (Kast et al., 1989; Lynch and Miller, 1991; Riddell et al., 1992; Rossemberg et al., 1994; Riddell and Greenberg, 1995; Henslop et al., 1996; Yee et al., 1997). Passive immunotherapy using T cells relies on the culture of autologous lymphocytes in the presence of a source of tumor antigens, professional antigen-presenting cells (APCs) and growth factors (Lynch and Miller, 1991; Yee et al., 1997). Low numbers of $\mathrm{T}$ cell precursors in tumor hosts could be simply a consequence of the lack of an ongoing antitumor response (Melero et al., 1997b; Wick et al., 1997) or the result of immune-suppressive mechanisms, displayed by the malignancy, that could lead to antigen-specific tolerance (Speiser et al., 1997; Chen, 1998).

The endogenous cellular immune response against tumor antigens can be boosted by a number of strategies, including vaccination with different formulations containing tumor antigens or by the administration of certain cytokines (Chen et al., 1993). The most successful procedures of active immunotherapy include: artificial presentation of tumor antigens on professional APCs or genetic modifications of tumor cells to mimic the functions of professional antigen-presentin $\mathrm{g}$ cells when producing cytokines and/or when expressing membrane-bound costimulatory molecules (cytokines) (Chen et al., 1993; Mayordomo et al., 1995).

Interleukin 12 (IL-12) is a cytokine with potent antitum or effects that result from its ability to stimulate cytotoxic $\mathrm{T}$ cells (CTLs), type 1 helper T cells (Th1 cells), and natural killer (NK) cells (Shurin et al., 1997) and to trigger a cascade of mediators that ultimately impair tumor angiogenesis (Siders et al., 1998; Tannenbaum et al., 1998). IL-12 has been delivered in vivo into the tumor environment by different recombinant viral vectors (Caruso et al., 1996; Toda et al., 1998), achieving tumor regressions and upregulation of the cellular immune response against malignant cells (Caruso et al., 1996; Toda et al., 1998). The intimate mechanisms behind IL-12 antitumor activity involve immune and nonimmune phenomena. Experimentation has shown that interferon $\gamma$ (IFN- $\gamma$ ), a major downstream mediator of IL-12 antitumor activity, is able to inhibit angiogenesis in malignant lesions through the induction of chemokines such as IFN- $\gamma$ inducible protein 10 (IP-10) (Siders et al., 1998). In some cases these mechanisms seem to be operational in the absence of conventional T cells (Boggio et al., 1998; Siders et al., 1998; Tannenbaum et al., 1998).

Recombinant defective adenoviruses have been shown to be an excellent vehicle to deliver IL-12 to experimental tumors including a poorly immunogenic colon carcinoma (Caruso et al., 1996; Mazzolini et al., 1999). In our hands, high levels of IL12 are produced on intratumoral injection of AdCMVIL-12 in CT26-derived tumors, leading to complete tumor regressions in $60-80 \%$ of cases. In such cases, a potent antitumor CTL response was detected, depletion of $\mathrm{CD} 8^{+}$cells abrogated the therapeutic effect, and a lymphocyte infiltrate accompanied tumor regressions (Mazzolini et al., 1999).

These findings provided the rationale for protocols of combination immunotherapy in which gene transfer with AdCMVIL-12 promotes the in vivo expansion of antitumor CTLs, thereby facilitating their subsequent in vitro culture for adoptive transfer. Our data demonstrate that active immunotherapy with AdCMVIL-12 not only permits CTL adoptive transfer by simplifying the obtention of the effector cells, but also synergizes with adoptive $\mathrm{T}$ cell therapy at the effector phase when both therapeutic strategies are used together to treat metastatic disease.

\section{MATERIALS AND METHODS}

\section{Animals, cell culture, and reagents}

Five- to 8-week-old BALB/c female mice were purchased from Charles River (Barcelona, Spain) and were housed according to institutional guidelines.

The 293 cell line (adenoviral E1-transformed human embryonic kidney cells) was obtained from American Type Culture Collection (ATCC, Rockville, MD). The BALB/c $\left(H-2^{d}\right)$ mouse-derived CT26 tumor cell line is an undifferentiated murine colorectal adenocarcinoma (Brattain et al., 1980) that was established from an $N$-nitroso- $N$-methylurethane-induced transplantable tumor (Corbett et al., 1975), obtained from K. Brand (Max-Planck-Institu t fur Biochemie, Munich, Germany). P815 and YAC-1 cells were obtained through the ATCC. The 293 cells were maintained in Dulbecco's modified Eagle's medium (DMEM) supplemented with $10 \%$ heat-inactivated fetal calf serum (FCS), $2 \mathrm{mM}$ L-glutamine, streptomycin (100 $\mathrm{U} / \mathrm{ml})$, and penicillin $(100 \mu \mathrm{g} / \mathrm{ml})$, CT2 26 cells were maintained in RPMI 1640 medium identically supplemented. Cell culture reagents were from GIBCO (Basel, Switzerland).

\section{Construction of adenovirus}

Recombinant adenovirus carrying IL-12 (AdCMVIL-12) has been previously described (Mazzolini et al., 1999). Briefly, an expression cassette of IL-12 under the control of the cytomegalovirus (CMV) promoter was constructed encom passing IL-12 p35 cDNA, an internal ribosomal entry site (IRES), IL12 p40 cDNA, and a polyadenylation signal. Recombinant adenovirus encoding the IL-12 cassette of expression was generated by cotransfection of 293 cells according to standard procedures (Qian et al., 1995). Adenovirus carrying the lacZ reporter gene under the control of the CMV promoter (AdCMVlacZ) was produced similarly. Recombinant adenoviruses were isolated from a single plaque, expanded in 293 cells, and purified by double cesium chloride ultracentrifugation (Qian et al., 1995). Purified virus was extensively dialyzed against 10 $\mathrm{m} M$ Tris- $1 \mathrm{~m} M \mathrm{MgCl}_{2}$ and stored in aliquots at $-80^{\circ} \mathrm{C}$, and it was carefully titrated by plaque assay.

\section{Peptides}

The H2-L ${ }^{\mathrm{d}}$-restricted peptides AH1 (SPSYVYHQF) (Huang et al., 1996) and P815AB (LPYLGWLVF) (Van den Eynde et al., 1991) were synthesized by 9-fluorenylmeth oxycarbonyl (Fmoc) chemistry as described (Prieto et al., 1995) and their purity confirmed by high-performan ce liquid chromatography (HPLC).

\section{T cell culture}

Mice carrying bilateral 5- to 8-mm (diameter) subcutaneous CT26 tumors were treated by intratumor injections of $10^{8} \mathrm{PFU}$ 
of AdCMVIL-12 or control adenovirus (AdCMVlacZ), or were left untreated. Draining lymph nodes were removed aseptically 5 days later and single-cell suspensions were obtained by pressing the lymph nodes mechanically through mesh screens. Lymph node cells were cultured in 24-well plates (Greiner Labortechnik, Frickenhausen, Germany) for 7 days at $5 \times 10^{6}$ cells/well with $2 \times 10^{5} \mathrm{CT} 26$ tumor cells/well pretreated for 1 $\mathrm{hr}$ at $37^{\circ} \mathrm{C}$ with mitomycin $\mathrm{C}(150 \mu \mathrm{g} / \mathrm{ml}$; Sigma, Madrid, Spain), a reagent that was extensively washed. Culture medium was complete RPMI 1640 supplemented on day 5 with murine IL-2 (mIL-2, 8-10 IU/ml; Peprotech, London, UK).

\section{${ }^{51} \mathrm{Cr}$ release assay}

Cytotoxicity was analyzed in conventional $5-\mathrm{hr}{ }^{51} \mathrm{Cr}$-release assays as described (Melero et al., 1997a). Briefly, ${ }^{51} \mathrm{Cr}$-loaded CT26, P815, and YAC-1 cells were incubated with effector cells at different effector-to-target $(E: T)$ ratios in triplicate wells and ${ }^{51} \mathrm{Cr}$ release $(\mathrm{cpm})$ into the supernatants was measured in a $\gamma$ counter to calculate percent specific release as described (Melero et al., 1997b). In some experiments, P815 cells were incubated during the assay with various concentrations of $\mathrm{AH} 1$ or P815AB peptide.

\section{Immunofluorescence and flow cytometry}

Double immunofluorescence staining with fluorescein isothiocyanate (FITC)-conjugated anti-CD8 and phycoerythrin (PE)-conjugate d anti-CD4 (PharMingen-Becton Dickinson, San Diego, CA) was carried out as previously described (Melero et al., 1997b). Electronically gated lymphocytes were analyzed on a FACscan (Becton Dickinson, Mountain View, CA).

In vivo treatment of CT26 tumors with recombinant adenovirus and adoptive transfer of lymphocytes

$\mathrm{BALB} / \mathrm{c}$ mice, in groups of seven or eight, were injected subcutaneously in the right hand flank with $5 \times 10^{5}$ CT26 cells in $25 \mu \mathrm{l}$ of phosphate-buffered saline (PBS). In some experiments, mice received in addition an identical dose of tumor cells injected surgically in the midlobe of the liver under general anesthesia. Subcutaneous tumors were injected with $10^{8} \mathrm{PFU}$ of recombinant adenovirus in $50 \mu$ of PBS. For cellular adoptive therapy, mice were injected intravenously with $5 \times 10^{6}$ cells from short-term CTL lines and given three intraperitoneal injections of $2 \times 10^{4}$ human recombinant IL-2 (Chiron, Emeryville, CA) in PBS on alternate days. Tumor size (mean diameter) was assessed by laparotomy, using a precision caliper. Statistical significance of the differences among groups was evaluated by Mann-Whitney tests for tumor sizes and log-rank test for survival.

\section{Immunomagnetic selection of $\mathrm{CD}^{+} \mathrm{T}$ cells and negative selection with MAb plus complement}

Cells from short-term CTL cultures were incubated with antiCD8-coated magnetic beads according to manufacturer instructions (Miltenyi Biotec, Bergisch Gladbach, Germany) and purified on a mini-MACS column (Miltenyi). Purity of CD8 ${ }^{+}$ cells was $98 \%$ as shown by fluorescence activated cell sorting (FACS) analysis. Depletion of $\mathrm{CD}^{+}$or $\mathrm{CD}^{+}$cells was achieved by treatment with culture supernatants from the hy- bridomas GK1.5 and H35.17.2 (ATCC) and rabbit complement (Sigma). Effectiveness of the procedure was routinely checked by FACS.

\section{IL-12 p70 quantitative assay}

To evaluate the production of IL-12 by the liver parenchyma and subcutaneous tumor, we injected AdCMVIL-12, AdCMVlacZ, or saline into subcutaneous tumors. Three days later, tissues were collected for determination of IL-12 p70 concentration by enzyme-linked immunosorbent assay (ELISA). To estimate the in vivo production of cytokines 3 days after treatment of the tumors with adenoviruses, liver and subcutaneous tumors were removed and frozen in liquid nitrogen. Frozen tissue was homogenized in $0.5 \mathrm{ml}$ of PBS containing $100 \mu M$ phenylmethylsu lfonyl fluoride (PMSF) and aprotinin (10 $\mu \mathrm{g} / \mathrm{ml}$; ICN Biomedicals) by Ultra-Turrax (Labortechnik, Staufen, Germany). The homogenate was then sonicated for 10 sec and cleared of debris by centrifugation in a microcentrifuge for $5 \mathrm{~min}$ at $4^{\circ} \mathrm{C}$. Samples were stored at $-20^{\circ} \mathrm{C}$.

The ELISA for IL-12 p70 was performed with a commercial kit (Endogen, Woburn, MA) according to manufacturer instructions, using superblocking buffer (Pierce, Rockford, IL).

\section{X-Gal histochemical staining}

Mice bearing both a subcutaneous and intrahepatic tumors were anesthetized with a mixture of ketamine and xylazine. AdCMVlacZ $\left(5 \times 10^{8} \mathrm{PFU}\right)$ in $50 \mu \mathrm{l}$ of saline was injected into the subcutaneous tumor. Two days later, animals were sacrificed and the livers were excised and immediately embedded in O.C.T. compound (Tissue Tek, Zoeterwoude, The Netherlands) and frozen in liquid nitrogen. Sections of $6-\mu \mathrm{m}$ thickness were fixed with glutaraldehyde $(0.5 \%)$ and stained with 5bromo-4-chloro- 3 -indolyl- $\beta$-D-galactopyranoside (X-Gal) as described previously (Qian et al., 1997).

\section{RESULTS}

\section{AdCMVIL-12 induces tumor regression and raises CTLs for adoptive therapy}

rIL-12 delivered by gene transfer procedures into tumors has been shown to inhibit tumor growth and to induce tumor regressions (Caruso et al., 1996; Toda et al., 1998). In our hands (Mazzolini et al., 1999), locally delivered AdCMVIL-12 induced the production of significant levels of IL-12 and displayed a potent effect against the CT26 colon carcinom a cell line forming either subcutaneous or intraheptic tumor nodules. In $60-80 \%$ of cases complete regressions were observed that were associated with an increase in tumor-specific CTL activity. Typically, a 5- to 8-mm (diameter) CT26 subcutaneous nodule treated with $10^{8}$ PFU of AdCMVIL-12 started to regress during the next 4-6 days, unless the mouse had been treated with a depleting anti-CD8 monoclonal antibody (MAb), conditions under which the antitumor effect was completely abrogated. Surgical and pathological examination revealed enlarged draining lymph nodes and an infiltrate of lymphocytes into the tumor. Accordingly, it was hypothesized that the obtention of CTL cultures aimed for adoptive therapy would be efficiently simplified in such animals. 
Since the CT26 cell line was derived from an adenocarcinoma arising from the colon, we established models in which $5 \times 10^{5}$ tumor cells were directly injected into the midlobe of the liver to give rise to intrahepatic tumors. These malignant nodules resemble those frequently observed in advanced human colon cancers. This model was employed to test whether treatment of CT26 tumors with AdCMVIL-12 would allow the generation of CTL cultures to be used in simple adoptive therapy protocols. Groups of four mice were injected subcutaneously and bilaterally with $5 \times 10^{5} \mathrm{CT} 26$, and after 10 days tumors (4-8 $\mathrm{mm}$ in diameter) were injected with AdCMVIL-12, a control recombinant adenovirus encoding $\beta$-galactosidase (AdCMVlacZ), or saline. Seven days later, mice were killed and cell suspensions of their draining lymph nodes were cocultured for 7 days with mitomicin C-treated CT26 cells. Such cell cultures were subsequently injected intravenously $\left(5 \times 10^{6}\right.$ cells/mouse) into mice hosting CT26 tumor cells inside their livers for 4 days prior to adoptive transfer. The adoptive trans-

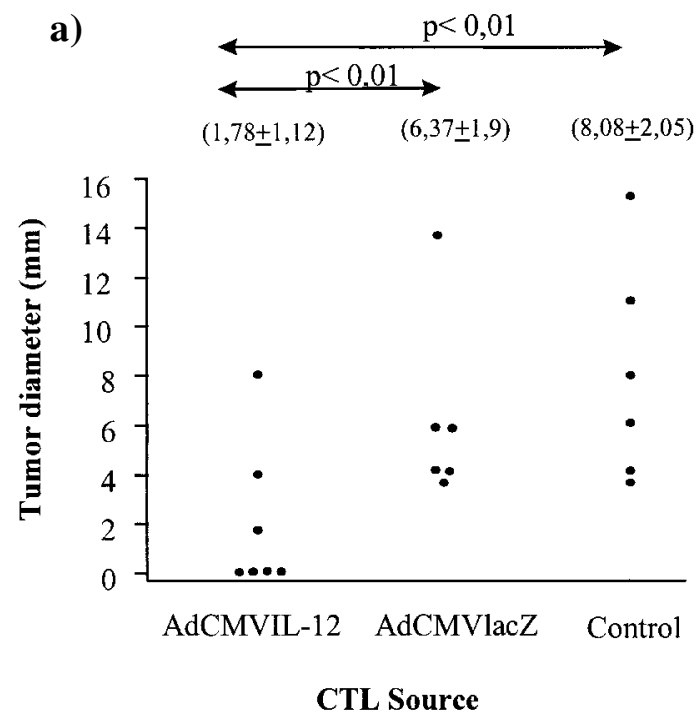

b)

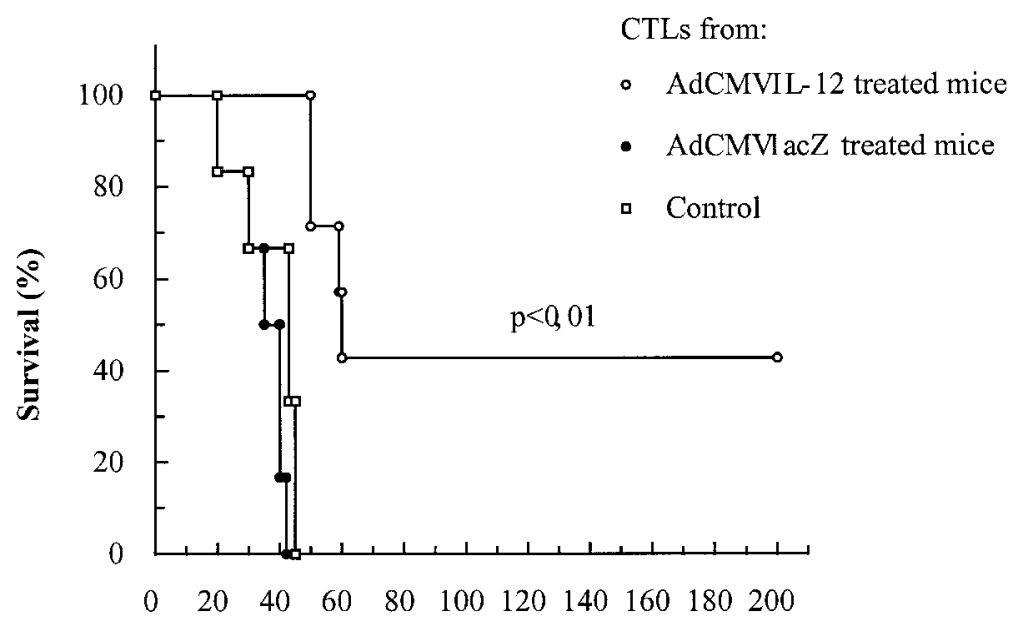

Days after tumor inoculation

FIG. 1. Intratumoral injection of AdCMVIL-12 raises CTL cultures effective for adoptive therapy. CTL cultures were set up by coculturing mitomycin C-treated CT26 cells with mononuclear cells from draining lymph nodes of mice bearing 4- to 8-mm subcutaneous CT26 tumors previously treated by intratumoral injections of $10^{8}$ PFU of AdCMVIL-12, $10^{8}$ PFU of AdCMVlacZ, or saline buffer. Three groups of mice, which had been injected with $5 \times 10^{5}$ viable CT26 cells in the midlobe of the liver on day 0 , were given on day $45 \times 10^{6}$ cells from each of the corresponding CTL cultures. Treatment was completed in every group by three doses (on alternate days) of $2 \times 10^{4}$ IU of hrIL-2. Tumor size (a) was assessed by surgical examination on day 14 and survival was monitored thereafter (b). Results were reproducible in three different experiments similarly performed (data not shown). 
fer of cells was supported in every case by the intraperitoneal injection of three doses of $2 \times 10^{4}$ IU of rIL-2 every 2 days to support the effect of injected $\mathrm{T}$ cells, as formerly described for these types of therapeutic regimens (Kast et al., 1989; Lynch and Miller, 1991). As shown in Fig. 1, only those mice into which were transferred CTL cultures obtained from mice treated with AdCMVIL-12 showed a marked decrease in tumor growth as assessed 14 days later by surgical examination. Follow-up survival studies of such animals showed slower tumor progression, in most instances with 40-60\% tumor eradications depending on the experiment (Fig. 1b). In some cases, the liver tumors observed in mice treated with CTLs obtained from the AdCMVlacZ groups were slightly smaller than those of mice treated with CTLs from the saline-treated groups, but complete regressions did not occur, nor was a clear extension of survival observed. It is worth mentioning that mice treated with CTL cultures from the lymph nodes of the saline control groups developed multiple peritoneal tumors that were not observed in the other groups, indicating that adoptive transfer had had a therapeutic effect to prevent or control these kinds of metastases (data not shown).

In conclusion, delivery of IL-12 by recombinant adenovirus allowed the induction of effective CTL populations for adoptive therapy.

\section{$\mathrm{CDS}^{+}$cells mediate the antitumor effect}

Our 7-days cocultures of lymph node cells from mice whose tumors had been treated with AdCMVIL-12 and nonproliferating CT26 cells contained cellular mixtures with $20-50 \% \mathrm{CD}^{+}$

a)

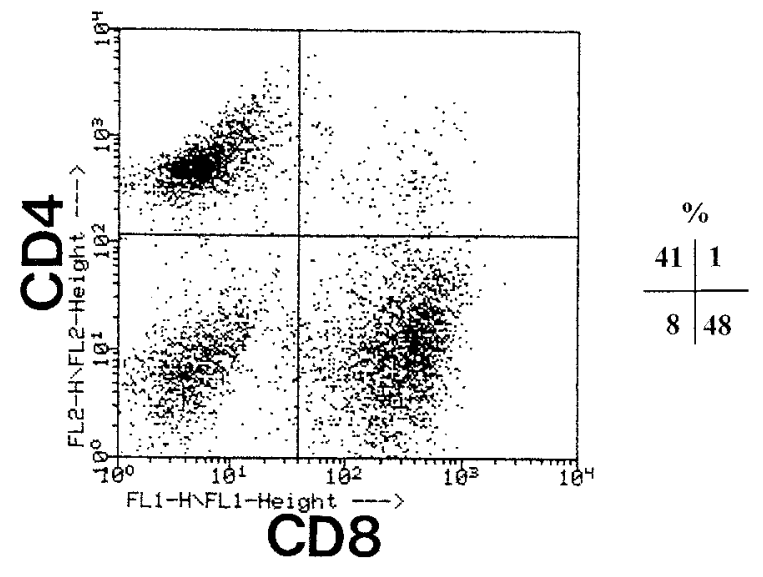

b)

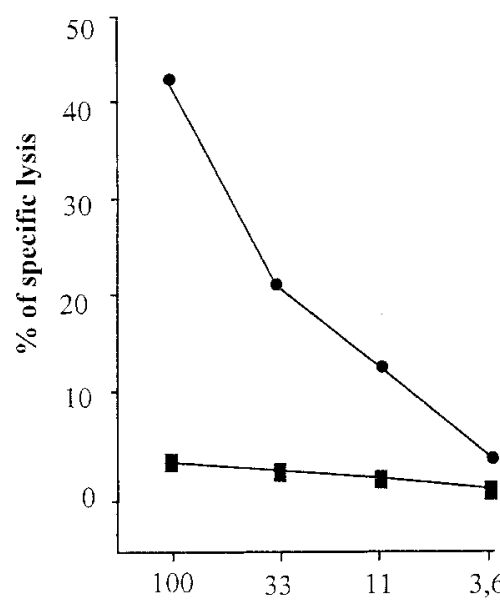

c)

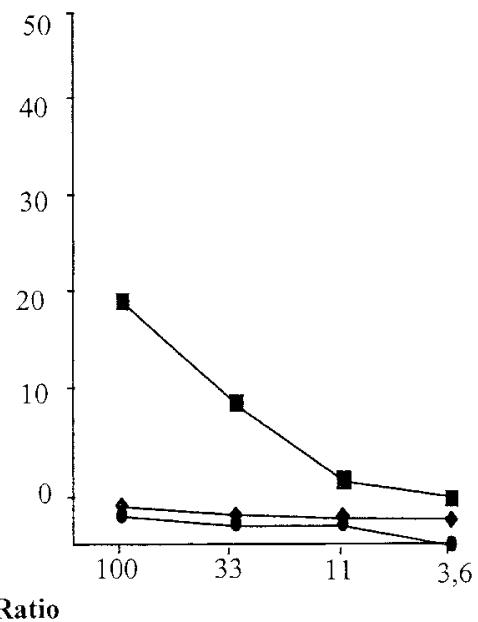

FIG. 2. Adoptively transferred $\mathrm{T}$ cell cultures contain anti-CT26-specific CTL activity. (a) FACS analysis after double staining by immunofluores cence with anti-CD4/anti-CD8 MAbs of a CTL culture obtained from mice whose subcutaneous CT26 tumors had been treated with AdCMVIL-12 as in Fig. 1. (b) Specific lysis against CT26 measured by standard ${ }^{51} \mathrm{Cr}$ release assays of CTL cultures obtained from mice bearing subcutaneous CT26 tumors injected with $10^{8}$ PFU of AdCMVIL-12 (circles) or AdCMVlacZ (squares). (c) Specific lysis of P815 cells pulsed during a ${ }^{51} \mathrm{Cr}$ release assay with $1 \mu M$ AH1 peptide (squares) or 1 $\mu M$ control irrelevant peptide (circles), or left unpulsed (diamonds), mediated by CTL cultures derived from mice whose tumors had been injected with $10^{8}$ PFU of AdCMVIL-12. 
T lymphocytes (Fig. 2a). Such lymphocyte populations displayed specific cytolytic activity against CT26, in contrast with cultures derived from mice bearing AdCMVlacZ- or salinetreated tumors. Indeed, CT26 cells were efficiently killed in vitro while the $\mathrm{P} 815$ mastocytoma cell line bearing identical MHC molecules was not (Fig. 2b). None of the cultures significantly lysed YAC-1 cells, indicating that NK activity was low in those lymphocyte cultures (data not shown). CTL clones obtained from mice immunized with CT26 granulocytemacrophage colony-stimulating factor (GM-CSF) transfectants have been used to identify an immunodominant antigenic peptide of the tumor presented by $\mathrm{H}-2 \mathrm{~L}^{\mathrm{d}}$. This peptide, termed AH1, was shown to be encoded by the env gene of the endogenous retrovirus Moloney murine leukemia virus (MoMuLV) (Huang et al., 1996). CTLs directed against this antigen were also present in the spleens of animals treated with a recombinant herpes viral vector encoding IL-12 (Toda et al., 1998). Results shown here (Fig. 2c) confirm that at least part of the CT26-specific CTL activity detected in our cultures was against this antigen when using P815 cells as targets pulsed with AH1 synthetic peptide.

The identity of the effector cells in the in vivo antitumor activity was addressed by negative and positive selection methods. Figure 3 displays results obtained in an experimental setting identical to the setting used in Fig. 1, but in this case CTL cultures obtained from mice whose subcutaneous tumors had been treated with AdCMVIL-12 were selectively depleted of $\mathrm{CD}^{+}$or $\mathrm{CD} 8^{+}$ cells by incubation in vitro with specific MAb plus rabbit complement before being used for adoptive therapy. Results show a critical involvement for $\mathrm{CD} 8^{+}$but not $\mathrm{CD} 4^{+} \mathrm{T}$ cells.
Table 1. Dose-Dependent Antitumor EFfect of $\mathrm{CD}^{+}$Cells

\begin{tabular}{lcc}
\hline & \multicolumn{2}{c}{ Tumor size $^{\mathrm{b}}$} \\
\cline { 2 - 3 } CTL dose & Individual sizes & Mean \\
\hline 0 & $10,9,20$ & 13 \\
$2 \times 10^{4}$ & $3,8,8.5$ & 6.5 \\
$2 \times 10^{5}$ & $0,5.5,8$ & 4.5 \\
$2 \times 10^{6}$ & $0,3,2$ & 1.7 \\
\hline
\end{tabular}

${ }^{\text {a Number of }} \mathrm{CD}^{+}$cells purified from CTL cultures by immunoselection with magnetic beads, adoptively transferred intravenously to mice hosting liver CT26 tumors 4 days prior to adoptive therapy. Purity of $\mathrm{CD} 8^{+}$cell suspensions was found to be above $98 \%$ by FACS analysis.

${ }^{b}$ Individual and mean tumor diameters, in millimeters. Size was measured by surgical inspection of the liver on day 12 after adoptive transfer.

In addition, when $\mathrm{CD}^{+}$cells were purified from the cultures by magnetic immunoselection yielding $98 \%$ purity, selected cells displayed a dose-dependent antitumor effect, indicating that $\mathrm{CD} 8^{+} \mathrm{T}$ cells were the necessary and sufficient populations for adoptive therapy (Table 1). Moreover, a lymphoid infiltrate was also observed in established CT26 tumors implanted in the liver of athymic $\mathrm{BALB} / \mathrm{c}^{\text {nude/nude }}$ mice that were treated intravenously with this CTL culture, thus clearly suggesting that adoptively transferred cells could home into the tumor tissue (data not shown).

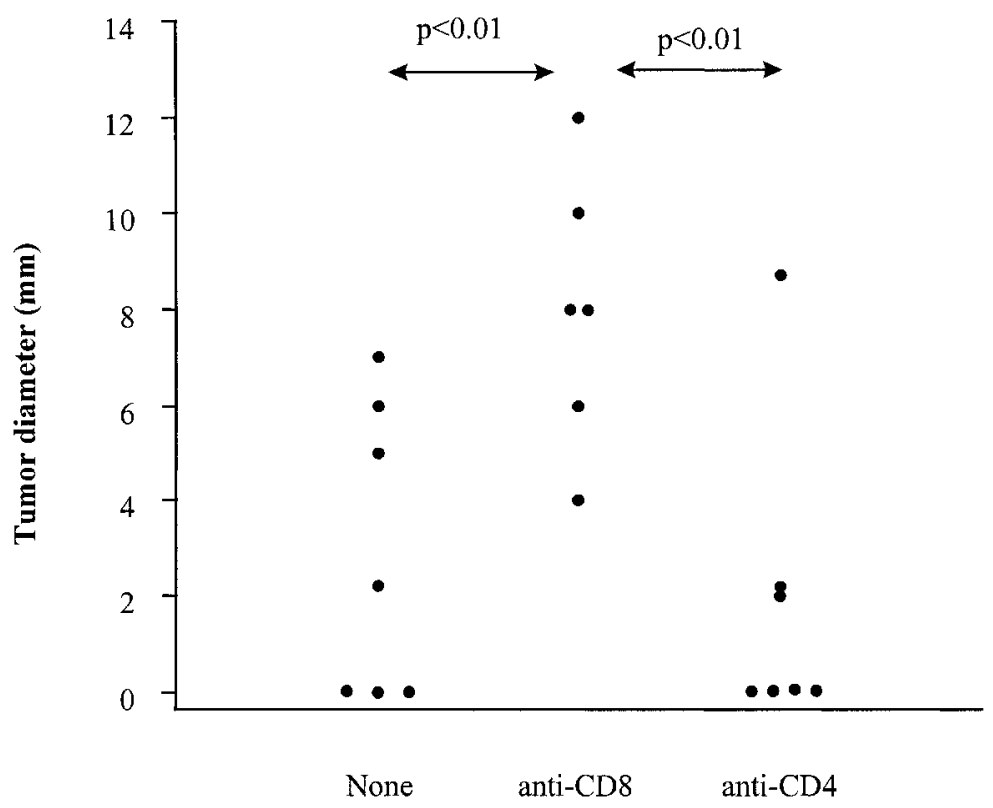

FIG. 3. $\mathrm{CD}^{+} \mathrm{T}$ cells are required for the antitumor effect of adoptive therapy. Cells $\left(5 \times 10^{6}\right)$ from the CTL cultures generated from draining lymph nodes of mice with subcutaneous CT26 tumors treated with AdCMVIL-12, under conditions identical to those in Fig. 1, were adoptively transferred intravenously to mice that harbored CT26 tumors implanted 4 days previously in the liver. In this case, prior to adoptive transfer, cultures were depleted of $\mathrm{CD}^{+}{ }^{+}$or $\mathrm{CD} 8^{+} \mathrm{T}$ cells by in vitro treatment with antiCD4 MAb, anti-CD8 MAb, or medium and subsequently treated with rabbit complement. Tumor sizes were monitored 10 days after adoptive therapy. 


\section{Adenoviral transfer of IL-12 into CT26 tumors displays a synergistic effect with adoptive transfer of antitumor $T$ lymphocytes}

The preceding data show that AdCMVIL-12 treatment benefits $\mathrm{T}$ cell adoptive therapy through its effect on the induction of a stronger CTL response, easing the in vitro obtention of effective $\mathrm{T}$ cell cultures. We then explored the possibility that AdCMVIL-12 and CTL cultures were also synergistic at the antitum or effector phase. In this case, the CTLs (obtained under culture conditions similar to those described above) were given 5 days after the intratumoral injection of AdCMVIL-12. A tumor model was established by injection of $5 \times 10^{5}$ CT26 cells, both subcutaneously in the left flank and inside the midlobe of the liver. In these animals, both tumors progressed and killed the animals if left untreated. This experiment was carried out to mimic the frequent condition of having a local colon carcinoma with the suspicion of or evidence that the malignancy has spread into the liver. In a first set of experiments, tumors were allowed to grow for 10 days to reach a size of $4-8 \mathrm{~mm}$ in both sites. Under such conditions, we verified that the formation of the subcutaneous and intrahepatic tumors did not in-

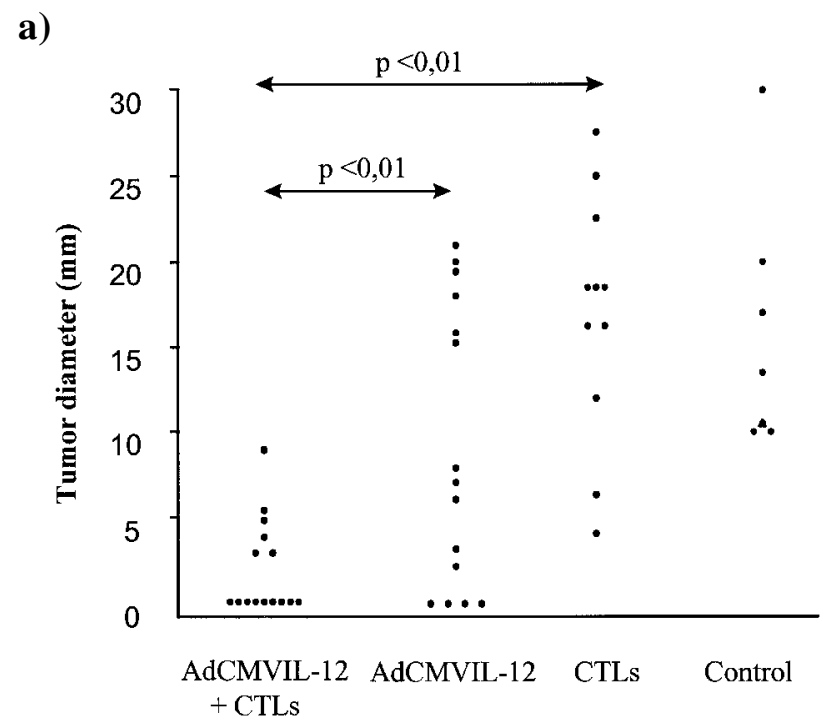

b)

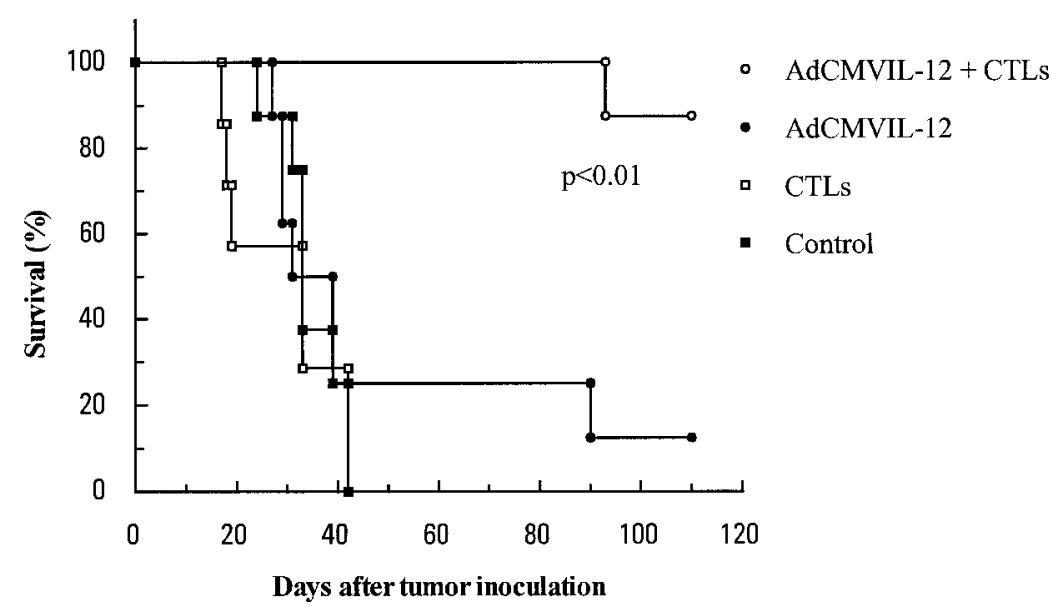

FIG. 4. Synergy of AdCMVIL-12 and T cell adoptive therapy in the treatment of distantly spread CT26 tumors. Mice hosting two CT26 tumors, one implanted subcutaneously and the other inside the midlobe of the liver, were divided in four groups that received the following injections: $10^{8} \mathrm{PFU}$ of AdCMVIL-12 in the subcutaneous tumor, $5 \times 10^{6}$ cells from the CTL cultures (intravenous), both treatments, or none. AdCMVIL-12 on day 10 and/or CTLs on day 15 after tumor inoculation were given to the indicated groups. The outcome was monitored by measuring the size of the liver on day 21 after tumor engraftment (a) or by following the survival of the different groups of mice (b). Every group received doses of $2 \times 10^{4}$ IU of rIL-2 intraperitoneally on three alternate days after the onset of treatment. Results represent pooled data from two different experiments sequentially performed. 
AdCMVIL-12 +CTLs

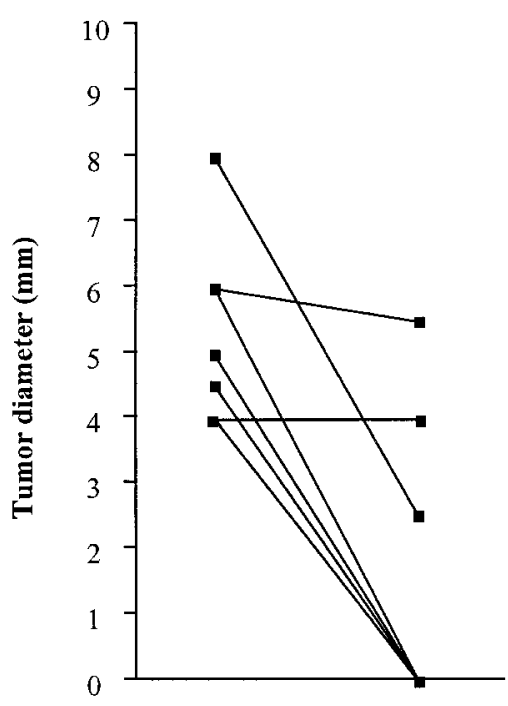

Before

treatment
After

treatment
AdCMVIL-12

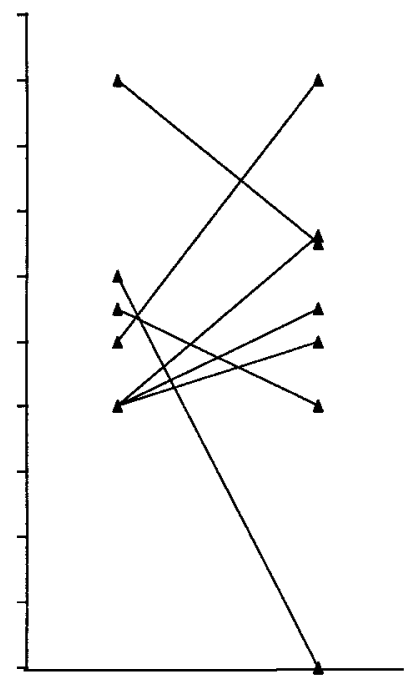

Before

treatment
After

treatment

FIG. 5. Local injection of suboptimal doses of AdCMVIL-12 into a CT26 tumor nodule inside the liver synergizes with systemic administration of anti-CT26 CTLs. Mice bearing a single CT26 tumor nodule in the midlobe of the liver were injected on day 10 after tumor implantation with $10^{7}$ PFU of AdCMVIL-12 with (left) or without (right) subsequent intravenous treatment by adoptive transfer of $5 \times 10^{6}$ cells from the CTL cultures. Individual size of tumor nodules was assessed before AdCMVIL12 injection as well as 8 days after injection. Both groups received a similar regimen of treatment with IL-2.

terfere with each other without treatment (data not shown). Then, as shown in Fig. 4, four groups of mice were studied. The first group received the intravenous injection of CTLs in addition to the injection of AdCMVIL-12 into the subcutaneous tumor nodule. The other three groups received only one of these treatments or none. When the liver tumors were surgically inspected 10 days after the onset of treatment, a marked antitumor effect was observed in the CTL + AdCMVIL-12 group, leading to the complete regression of the hepatic tumors in 9 of 16 cases and with a clear decrease in the remaining tumor sizes. Single inoculation of AdCMVIL-12 into the subcutaneous site, but without CTL transfer, displayed only limited antitum or activity at the liver site. In the case of mice receiving only CTLs, no activity was detected against these relatively large nodules. Survival data confirmed these observations (Fig. 4b) and suggested that some tumors still detected on day 10 posttherapy eventually regressed. It is noteworthy that CTLs by themselves were efficacious against small tumor burdens (Fig. 1) but were unable to treat larger tumor nodules (Fig. 4).

It is interesting that combined therapy also improved the effect of AdCMVIL-12 injection at the local dermal site. In the follow-up of the subcutaneous tumor nodules, 14 of 15 cases receiving combined therapy completely regressed whereas only 10 of 15 regressed in those mice receiving AdCMVIL-12 only (data not shown). In the group receiving the infusion of CTLs but without AdCMVIL-12 only 1 regression of the subcutaneous nodule was observed of 10 mice, in comparison with none in the control group (data not shown). These data sug- gested that there was also synergy between local treatment by AdCMVIL-12 and the systemic administration of CTLs. To further confirm these observations, hepatic tumors were given an intratumoral injection of $10^{7}$ PFU of AdCMVIL-12, a dose that had been found to be suboptimal for liver tumors implanted 10 days before treatment (G. Mazzolini, unpublished observations, 1998). Under these suboptimal conditions the intravenous infusion of CTLs on day 15 after injection of tumor cells was responsible for a marked improvement in efficacy in reducing the size of the tumors on day 21 (Fig. 5). Such data confirm the synergy observed at the effector phase of AdCMVIL-12 + CTLs combined therapy when studied locally at the adenovirally transduced tumor site.

\section{Recombinant adenovirus injected in the subcutaneous tumor nodule gains access to liver parenchyma}

To address the mechanisms underlying the effects on the liver tumors induced by injecting AdCMVIL-12 into a concurrent subcutaneous tumor nodule, several experiments were carried out. In a group of mice carrying concomitantly a subcutaneous CT26 tumor and intrahepatic tumor nodules, the subcutaneous tumor was treated with $5 \times 10^{8} \mathrm{PFU}$ of AdCMVlacZ. Frozen sections of the midlobe of the liver of such animals harvested 2 days later were stained for $\beta$-galactosidase activity. On microscopic examination, scattered strongly positive cells were detected in the healthy liver parenchyma (Fig. $6 \mathrm{~B})$. It is interesting that an intense positive staining was detected in the liver tissue surrounding tumor nodules, thus de- 
picting a rim of transduced cells. Also, some cells stained positive within such malignant lesions (Fig. 6A).

In a similar setting IL-12 p70 was detected by ELISA in homogenates of liver tissue when the subcutaneous tumor had been treated with AdCMVIL-12 $\left(5 \times 10^{8}\right.$ PFU) (Fig. 6C). Liver IL-12 concentrations per $100 \mathrm{mg}$ of tissue were at least 10 times lower than that observed in the subcutaneous malignant nodule, which received the AdCMVIL-12 dose directly (Fig. 6D).

Our data strongly suggest a role for "leaky" adenovirus reaching the systemic circulation and eventually infecting the liver tissue in the observed therapeutic synergy. Such a phenomenon establishes a link between treatment of the subcutaneous tumor and the effects on the experimental metastasis in the liver.

\section{DISCUSSION}

The present study provides evidence that the efficacy of adoptive therapy with CTLs can be enhanced by active im-

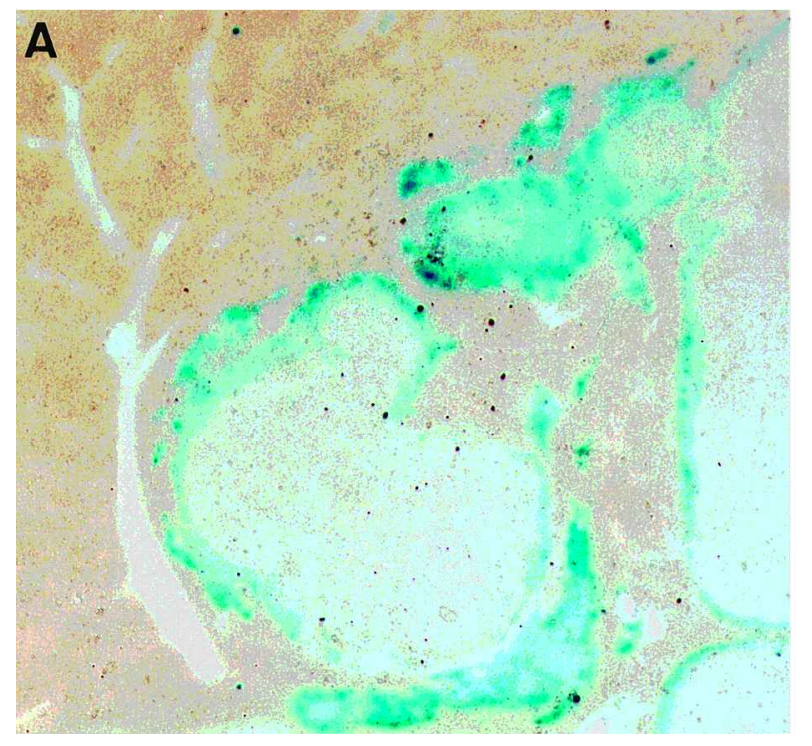

C

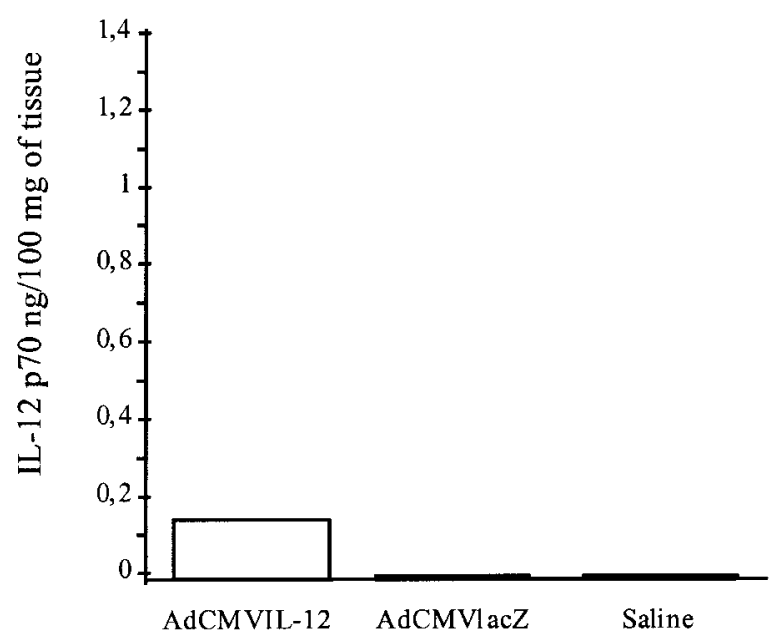

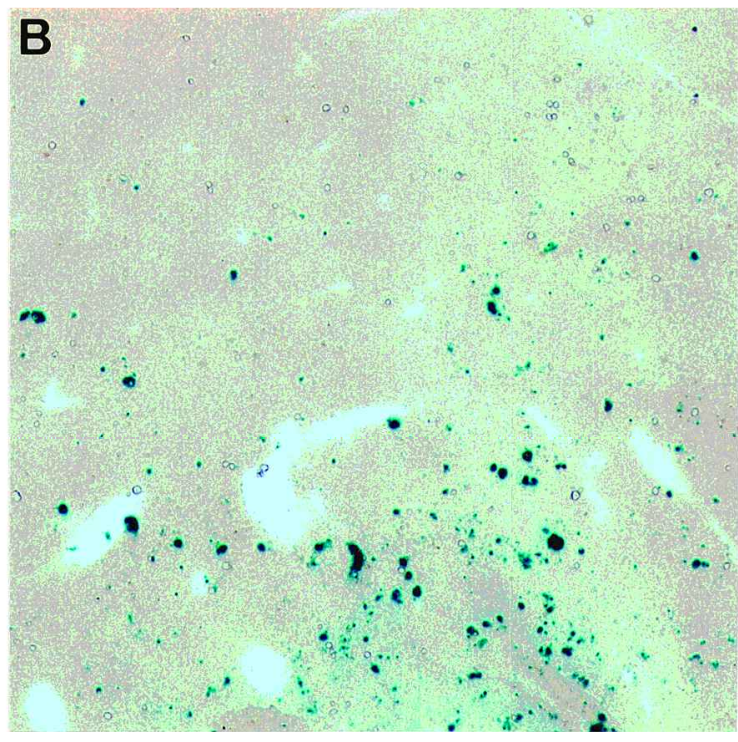

D

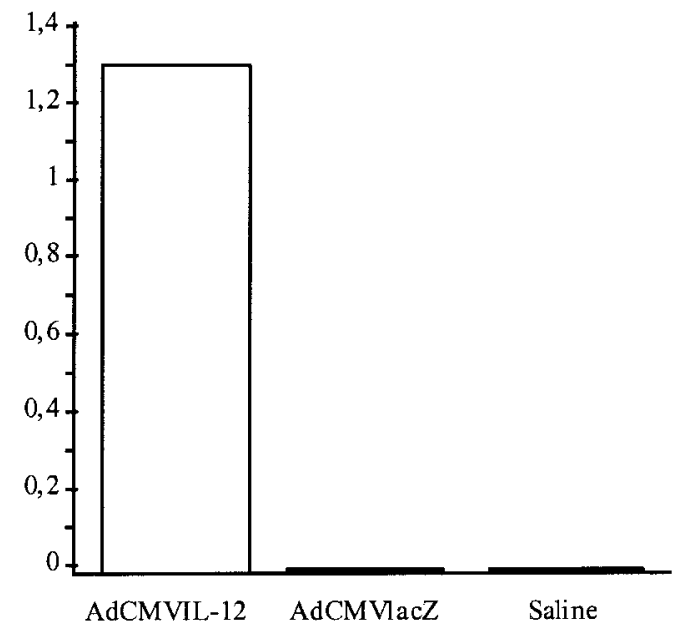

FIG. 6. Liver cells express the transgene encoded by a recombinant adenovirus injected into a subcutaneous tumor nodule. (A and B) Frozen sections of livers carrying CT26 tumor nodules stained by X-Gal that had been obtained from mice carrying a concomitant subcutaneous tumor treated with $5 \times 10^{8}$ PFU of AdCMVlacZ 2 days prior to liver harvest. In (A) healthy liver and tumor nodules are shown $(\times 10)$ in $(\mathbf{B})$ healthy liver parenchyma is shown with greater magnification $(\times 20)$. $(\mathbf{C}$ and $\mathbf{D})$ IL-12 p70 concentration per $100 \mathrm{mg}$ of tissue obtained by ELISA in homogenates of (C) liver tissue and (D) concomitant subcutaneous tumor nodules injected with the indicated adenovirus or saline buffer 3 days prior to tissue collection. The concentration of IL12 in tissue samples treated with AdCMVlacZ or saline was under the detection threshold of the ELISA (15 pg/ml). Data are representative of two different experiments. 
munotherapy, as provided by an IL-12-encoding adenoviral vector. Thus, gene transfer of IL-12 into CT26 tumors improves the yield of tumor-specific CTLs in short-term cultures. Moreover, systemic treatment with those CTL cultures and infection of the tumor tissue with AdCMVIL-12 show synergy not only against tumor nodules transduced with the recombinant adenovirus but also against distant, nonadenovirally transduced tumor sites.

IL-12 has been shown to promote CTL precursor expansion and differentiation both in vitro and in vivo (Trinchieri, 1998). Since functional IL-12 receptors (IL-12Rs) have been detected on $\mathrm{CD}^{+} \mathrm{T}$ cells, upregulation of CTL activity could result in part from direct effects of the cytokine on this $\mathrm{T}$ cell subset (Trinchieri, 1998). However, IL-12 also activates IFN- $\gamma$ secretion and other functions from other cell types such as helper $\mathrm{T}$ lymphocytes and NK cells that can subsequently promote CTL expansion and activation (Topalian, 1994; Kos and Engleman, 1996). The importance and need of helper $T$ populations for the IL-12-boosted antitumor response vary with the different tumor cell lines and experimental systems. Using IL-12 transfectants in CT26, it has been reported that $\mathrm{CD}_{4}^{+} \mathrm{T}$ cells have a deleterious effect on the antitumor response otherwise mediated by $\mathrm{CD}^{+} \mathrm{T}$ cells and NK cells (Martinotti et al., 1995). However, it is conceivable that CTL generation, even in the CT26 setting, can be favored by Th1 cells that secrete IL-2 and IFN- $\gamma$ (Trinchieri, 1998) and that are able to license professional APCs for activation of CTL precursors (Lanzavecchia, 1998; Ridge et al., 1998). In fact, antitumor effects mediated by CD $4^{+}$cells have been reported by the same group when the IL-12 transfectants are injected into IFN- $\gamma$ receptor knockout mice (Zilocchi et al., 1998). In this regard, too-high doses of IL-12 have been reported to downregulate the $\mathrm{T}$ cell response, acting through an excess of IFN- $\gamma$ (Kurzawa Koblish et al., 1998; Lasarte et al., 1999).

Regardless of the complexity of the mechanisms whereby IL12 augments the CTL response against CT26, we have observed that anti-CT26 CTL activity could be detected only after gene transfer of IL-12 into the tumors. Our short-term CTL lines were, at least in part, directed to the AH1 tumor antigen encoded by the env gene of an endogenous retrovirus, present in the genome of normal $\mathrm{BALB} / \mathrm{c}$ mice, which is expressed by the CT26 tumor cell line (Huang et al., 1996). Similar results of specificity had been obtained using a herpesvirus-based vector to transfer IL-12 expression into CT26 tumors in vivo (Toda et al., 1998). Our CTL cultures did not lyse unpulsed P815 cells or YAC-1 cells, thus excluding lack of specificity. Even though CTL clones, rather than short-term CTL lines are usually preferred for $\mathrm{T}$ cell adoptive therapy, an early-passaged CTL line may be advantageous in preventing tumor antigen escape variants, because they are less selected by immunodominant antigens and can recognize more than one epitope. Experimentation in progress in our laboratory is comparatively testing the use of long-term versus short-term CTL lines in various in vivo tumor models.

Adoptive T cell therapy (Ridell and Greenberg, 1995; Yee et al., 1997) against tumor antigens has been successfully used in a number of cases (Kast et al., 1989; Lynch and Miller, 1991; Ridell and Greenberg, 1995; Yee et al., 1997). We show that short-term CTL cultures from mice whose tumors were undergoing AdCMVIL-12-induced regression displayed a potent effect against small CT26 tumors implanted as cell suspensions in the liver, 4 days prior to adoptive therapy. Such an effect was not observed in identical lymphocyte cultures obtained from CT26 tumor-bearing animals treated with a control adenovirus or left untreated, indicating the dependence of CTL activity on the expression of the IL-12 transgene. These data imply that intratumoral treatment with AdCMVIL-12 simplifies the subsequent in vitro growth of effective CTLs. Although adoptively transferred $\mathrm{CD}^{+}$cells have displayed antitumor activity in some systems (Hu et al., 1993), the presence of CD4 ${ }^{+}$ $\mathrm{T}$ cells in our adoptively transferred cultures is not a requirement and only the depletion of $\mathrm{CD}^{+}$cells abrogated their in vitro and in vivo activity. Moreover, purified $\mathrm{CD} 8^{+}$cells from those cultures were sufficient to execute, in a dose-dependent manner, the antitum or effect on adoptive transfer. These results exclude a relevant role for other minor cell populations such as dendritic cells that could be present in our short-term $\mathrm{T}$ cell cultures. As a broader interpretation of these experiments, we postulate that protocols of adoptive immunotherapy will benefit from previous active immunotherapy approaches perform ed on the same patient, which thereby augment the number of responding $\mathrm{T}$ cells available for their subsequent in vitro expansion. Among the candidates for those active therapy procedures are the gene transfer of cytokines or costimulatory molecules to the tumor mass (Chen et al., 1993) and/or vaccination with tumor antigens presented by dendritic cells (Mayordomo et al., 1995). However, we cannot confirm that adoptively transferred antitum or CTLs carry out their effects only the basis of their tumor-specific cytolytic potential since their ability to secrete different cytokines can also be involved.

Intratumoral injection of AdCMVIL-12 into CT26 tumors causes tumor regressions in $60-80 \%$ of cases (Mazzolini et al., 1999). In several systems it has been shown that IFN- $\gamma$ is the main downstream mediator of the IL-12 antitumor effects. In the liver, a key role for NK T cells as a source of IFN- $\gamma$ in the antitum or response induced by IL-12 has been identified using gene-targeted mice (Cui et al., 1997). IFN- $\gamma$ in turn induces a plethora of effects not only on immune system cells but also on tumor cells, making them prone to be lysed by CTLs (Coughlin et al., 1998). Evidence shows that the chemokines IP-10 and Mig (monokine induced by IFN- $\gamma$ ) are induced by IFN- $\gamma$, on administration of IL-12, and mediate a potent tumor angiogenesis inhibition, while theoretically they also drive activated $\mathrm{T}$ cells to the tumor tissue.

Experiments carried out in mice bearing two distant tumor nodules, subcutaneous and intrahepatic, have found that injection of AdCMVIL-12 in one tumor site (subcutaneous nodule) has therapeutic effects on the second nodule, but only in a minority of cases. In contrast with the timid therapeutic effect on the liver tumor induced by AdCMVIL-12 injected into the subcutaneous nodule, combined administration of intravenously, adoptively transferred CTLs and injection of AdCMVIL-12 in the subcutaneous tum or nodule causes a dramatic antitumor effect against relatively large, well-established intrahepatic metastasis and further improved the outcome of subcutaneous tumor nodules them selves. Our current research is trying to disentangle the main molecular mechanisms behind the observation of the synergy phenomenon. A major question is whether IL-12 and/or IFN- $\gamma$ can act at the distant, nonadenovirally transduced tumor site. In some reported models (Bramson et al., 1997) and in our hands, a fraction of the adenovirus injected 
into the tumor gains access to the systemic circulation and infects the healthy liver parenchyma, giving rise to expression of the transgene. Secretion of IL-12 in the liver can set in motion a cascade of proinflammatory cytokines potentially cooperative with adoptively transferred CTLs and with direct antitumor activity. The above-mentioned studies of NK T cell-deficient mice (Cui et al., 1997) predict a role for these liver-located lymphocytes in the overall process that is being addressed. If this scenario of local cytokine secretion inside the liver is important for the observed synergistic effect, then it might be advantageous to treat liver metastasis but perhaps not as powerful to treat the extension of the disease to other organs. Nonetheless, liver metastases are frequent, often fatal, complications of colon cancer. It is interesting that transgene-expressing cells were much more frequent in the liver tissue located in the immediate neighborhood of the malignant nodules. Such transduced cells form a sort of rim around the tumor nodules and could be involved in the observed therapeutic effects. Our current research is dealing with the molecular mechanisms explaining the selectivity of infection around the malignant tissue.

IL-2 and other cytokines are routinely used to potentiate adoptive therapy. In our protocols we injected rIL-2 intraperitoneally in all the experimental groups because of the belief that fully differentiated CTLs cannot produce IL-2 (Kast et al., 1989; Lynch and Miller, 1991; Ridell and Greenberg, 1995; Yee et al., 1997). Along this line, data show that coinjection into tumor tissue of two different recombinant adenoviruses encoding IL-12 and IL-2 had a marked synergistic effect (Addison et al., 1998), which likewise had been observed with the recombinant cytokines. However, the IL-2 doses given in our adoptive transfer protocols did not display measurable antitumor activity by themselves.

Our preliminary data indicate that AdCMVIL-12 injection into a subcutaneous CT26 tumor enhances the expression of vascular cell adhesion molecule 1 (VCAM-1) on the endothelial cells present within concomitant liver tumor nodules. We are exploring whether this phenomenon favors the homing of antitum or lymphocytes into malignant tissue as has been suggested (Ogawa et al., 1997), thus providing a mechanistic view of the observed effector-phase synergy (G. Mazzolini, unpublished observations, 1998). In light of the data showing expression of the transgene in the liver, the IL-12-triggered cascade of cytokines might be responsible for this local upregulation of VCAM-1.

Taken together, our data provide evidence of a potent synergy between $\mathrm{T}$ cell adoptive therapy and gene transfer of IL12 into tumor tissue. Both therapies cooperate at least at two different levels: (1) AdCMVIL-12 treatment enhances CTL responses and facilitates their in vitro culture; and (2) systemic administration of CTLs and local treatment with AdCMVIL-12 display a potent effect against metastatic disease. Such a combined therapeutic strategy, rather than having an additive effect, shows a powerful synergy that should not be overlooked in the design of future clinical applications.

\section{ACKNOWLEDGMENTS}

We are grateful to our colleagues Drs. Ruiz, Lasarte, Sarobe, Sangro, and Bustos for critical reading of the manuscript and helpful suggestions.
This work was supported by grants from I. Bemberg, J. Vidal, and M. Mendez, and by SAF98-0146 and SAF99-0039 from CICYT (Spain).

\section{REFERENCES}

ADDISON, C.L., BRAMSON, J.L., HITT, M.M., MULLER, W.J., GAULDIE, J., and GRAHAM, F.L. (1998). Intratumoral coinjection of adenoviral vectors expressing IL-2 and IL-12 results in enhanced frequency of regression of injected and untreated distal tumors. Gene Ther. 5, 1400-1409.

BOGGIO, K., NICOLETTI, G., DI CARLO, E., CAVALLO, F., LANDUZZI, L., MELANI,C., GIOVARELLI, M., ROSSI, I., NANNI, P., DE GIOVANNI, C., BOUCHARD, P., WOLF, S., MODESTI, A., MUSIANI, P., LOLLINI, P.L., COLOMBO, M.P., and FORNI, G. (1998). Interleukin 12-mediated prevention of spontaneous mammary adenocarcinom as in two lines of Her-2/neu transgenic mice. J. Exp. Med. 188, 589-596.

BRAMSON, J.L., HITT, M., GAULDIE, J., and GRAHAM, F.L. (1997). Pre-existing immunity to adenovirus does not prevent tumor regression following intratumoral administration of a vector expressing IL-12 but inhibits virus dissemination. Gene Ther. 4, 1069-1076

BRATTAIN, M.G., STROBEL STEVENSON, J., FIND, D., WEBB, M., and SARRIF, A.M. (1980). Establishment of mouse colonic carcinoma cell lines with different metastatic properties. Cancer Res. 40, 2142-2146.

CARUSO, M., PHAM-NGUYEN, K., KWONG, Y.-L., XU, B., KOSAI, K.-I., FINEGOLD, M., WOO, S.L.C., and CHEN, S.-H. (1996). Adenoviral-mediated interleukin-12 gene therapy for metastatic colon carcinoma. Proc. Natl. Acad. Sci. U.S.A. 93, 11302-11306.

CHEN, L. (1998). Immunological ignorance of silent antigens as an explanation of tumor evasion. Self antigens expressed by solid tumors do not efficiently stimulate naive or activated T cells: Implications for immunotherapy. Immunol. Today 19, 27-30.

CHEN, L., LINSLEY, P.S., and HELLSTRÖM, K.E. (1993). Costimulation of T cells for tumor immunity. Immunol. Today 14, 483-485.

CORBETT, T.H., GRISWALD, D.D., ROBERTS, B.J., PECKHAM, J.C., and SCHABEL, F.M. (1975). Tumor induction relationships in development of transplantable cancers of the colon in mice for chemotherapy assay with a note on carcinogen structure. Cancer Res. 35, 2434-2439.

COUGHLIN, C.M., SALHANY, K.E., GEE, M.S., LATEMPLE, D.C., KOTENKO, S., MA, X., GRI, G., WYSOCKA, M., KIM, J.E., LIU, L., LIAO, F., FARBER, J.M., PESTKA, S., TRINCHIERI, G., and LEE, W.M.F. (1998). Tumor cell responses to IFN $\gamma$ affect tumorigenicity and response to IL-12 therapy and antiangiogenesis. Immunity $9,25-34$.

CUI, J., SHIN, T., KAWANO, T., SATO, H., KONDO, E., TOURA, I., KANEDO, Y., KOSEKI, H., KANNO, M., and TANIGUCHI, M. (1997). Requirement for $\mathrm{V}_{\alpha} 14$ NKT cells in IL-12-mediated rejection of tumors. Science 278, 1623-1626.

HENSLOP, H.E., NG, C.Y.C., LI, C., SMITH, C.A., LOFTIN, S.K., KRANCE, R.A., BRENNER, M.K., and ROONEY, C.M. (1996). Long-term restoration of immunity against Epstein-Barr virus infection by adoptive transfer of gene-modified virus-specific $\mathrm{T}$ lymphocytes. Nature Med. 2, 551-555.

HU, J., KINDSVOGEL, W., BUSBY, S., BAILEY, C., SHI, Y., and GREENBERG, P.D. (1993). An evaluation of the potential to use tumor-associated antigens as targets for antitumor $\mathrm{T}$ cell therapy using transgenic mice expressing a retroviral tumor antigen in normal lymphoid tissues. J. Exp. Med. 177, 1681-1690.

HUANG, A.Y.C., GULDEN, P.H., WOODS, A.S., THOMAS, M.C., TONG, C.D., WANG, W., ENGELHARD, V.H., PASTERNACK, 
G., COTTER, R., HUNT, D., PARDOLL, D.M., and JAFFEE, E.M. (1996). The immunodominant major histocompatibility complex class I-restricted antigen of a murine colon tumor derives from an endogenous retroviral gene product. Proc. Natl. Acad. Sci. U.S.A. 93, 9730-9735.

KAST, W.M., OFFRINGA, R., PETERS, P.J., VOORDOUW, A.C., MELOEN, R.H., VAN DER EB, A.J., and MELIEF, C.J.M. (1989), Eradication of adenovirus E1-induced tumors by E1A-specific cytotoxic T lymphocytes. Cell 59, 603-614.

KOS, F.J., and ENGLEMAN, E.G. (1996). Immune regulation: A critical link between NK cells and CTLs. Immunol. Today 17, 174-176.

KURZAWA KOBLISH, H., HUNTER, C.A., WYSOCKA, M., TRINCHIERI, G., and LEE, W.M.F. (1998). Immune suppression by recombinant interleukin (rIL)-12 involves interferon $\gamma$ induction of nitric oxide synthase 2 (iNOS) activity: Inhibitors of NO generation reveal the extent of rIL-12 vaccine adjuvant effect. J. Exp. Med. 188, 1603-1610.

LANZA VECCHIA, A. (1998). Licence to kill. Nature (London) 293, $413-414$.

LASARTE, J.J., CORRALES, F.J., CASARES, N., LOPEZ-DIAZ DE CERIO, A., QIAN, C., XIE, X., BORRAS-CUESTA, F., and PRIETO, J. (1999). Different doses of adenoviral vector expressing IL12 enhance or depress the immune response to a coadministered antigen: The role of nitric oxide. J. Immunol. 162, 5270-5277.

LYNCH, D.H., and MILLER, R.E. (1991). Immunotherapeutic elimination of syngeneic tumors in vivo by cytotoxic T lymphocytes generated in vitro from lymphocytes from the draining lymph nodes of tumor-bearing mice. Eur. J. Immunol. 21, 1403-1410.

MARTINOTTI, A., STOPPACCIARO, A., VAGLIANI, M., MELANI, C., SPREAFICO, F., WYSOCKA, M., PARMIANI, G., TRINCHIERI, G., and COLOMBO, M.P. (1995) CD4 T cells inhibit in vivo the $\mathrm{CD} 8$-mediated immune response against murine colon carcinoma cells transduced with interleukin-12 genes. Eur. J. Immunol. 25, 137-146.

MAYORDOMO, J.I., ZORINA, T., STORKUS, W.J., ZITVOGEL, L., CELluZZI, C., FALO, L.D., MELIEF, C.J., ILDSTAD, S.T., KAST, W.M., DELEO, A.B., and LOTZE, M.T. (1995). Bone marrow-derived dendritic cells pulsed with synthetic tumour peptides elicit protective and therapeutic antitumour immunity. Nature Med. 1, 1297-1302.

MAZZOLINI, G., QIAN, C., XIE, X., SUN, Y., LASARTE, J.J., DROZDZIK, M., and PRIETO, J. (1999). Regression of colon cancer and induction of antitumor immunity by intratumoral injection of adenovirus expressing IL-12. Cancer Gene Ther. (in press).

MELERO, I., SHUFFORD, W.W., ASHE-NEWBY, S., ARUFFO, A., LEDBETTER, J.A., HELLSTRÖM, K.E., MITTLER, R.S., and CHEN, L. (1997a). Monoclonal antibodies against the 4-1BB T-cell activation molecule eradicate established tumors. Nature Med. 3, 682-685.

MELERO, I., SiNGHAL, M.C., McGOWAN, P., HAUGEN, H.S., BLAKE, J., HELlSTRÖM, K.E., YANG, G., CLEGG, C.H., and CHEN, L. (1997b). Immunological ignorance of an E7-encoded cytolytic T-lymphocyte epitope in transgenic mice expressing the E7 and E6 oncogenes of human papillomavirus type 16. J. Virol. 71, 3998-4004.

OGAWA, M., TSUTSUI, T., ZOU, J.-P., MU, J., WIJESURIYA, R., YU, W.-G., HERRMANN, S., KUBO, T., FUJIWARA, H., and HAMAOKA, T. (1997). Enhanced induction of very late antigen 4/lymphocyte function-associated antigen 1-dependent T-cell migration to tumor sites following administration of interleukin 12. Cancer Res. 57, 2216-2222.

PRIETO, I., HERVÁS-STUBBS, S., GARCIA-GRANERO, C., BERASAÍN, C., RIEZU-BOJ, J.I., LASARTE, J.J., SAROBE, P., PRIETO, J., and BORRÁS-CUESTA, F. (1995). Simple strategy to in- duce antibodies of distinct specificity: Application to the mapping of gp120 and inhibition of HIV-1 infectivity. Eur. J. Immunol. 25, $877-883$.

QIAN, C., BILBAO, R., BRUÑA, O., and PRIETO, J. (1995). Induction of sensitivity to ganciclovir in human hepatocellular carcinoma cells by adenovirus-mediated gene transfer of herpes simplex virus thymidine kinase. Hepatology 22, 118-123.

QIAN, C., IDOATE, M., BILBAO, R., SANGRO, B., BRUÑA, VÁZQUEZ, J., and PRIETO, J. (1997). Gene transfer and therapy with adenoviral vector in rats with diethylnitrosamin e-induced hepatocellular carcinoma. Hum. Gene Ther. 8, 349-358.

RIDDELL, S.R., and GREENBERG, P.D. (1995). Principles for adoptive $\mathrm{T}$ cell therapy of human viral diseases. Annu. Rev. Immunol. 13, 545-586.

RIDDELL, S.R., GREENBERG, P.D., OVERELL, R.W., LOUGHRAN, T.P., GILBERT, M.J., LUPTON, S.D., AGOSTI, J., SCHELLER, S., COOMBS, R.W., and COREY, L. (1992). Phase I study of cellular adoptive immunotherapy using genetically modified CD8 + HIV-specific T cells for HIV seropositive patients undergoing allogeneic bone marrow transplant. The Fred Hutchinson Cancer Research Center and the University of Washington School of Medicine, Department of Medicine, Division of Oncology. Hum. Gene Ther. 3, 319-338.

RIDGE, J.P., DI ROSA, F., and MATZINGER, P. (1998). A conditioned dendritic cell can be a temporal bridge between a CD4 $+\mathrm{T}$ helper and a T-killer cell. Nature (London) 393, 474-478.

ROSSEMBERG, S.A., YANNELLI, J.R., YANG, J.C., TOPALIAN, S.L., SCHWARTZENTRUBER, D.J., WEBER, J.S., PARKINSON, D.R., SEIPP, C.A., EINHORN, J.H., and WHITE, D.E. (1994). Treatment of patients with metastatic melanoma with autologous tumor-infiltrating lymphocytes and interleukin 2. J. Natl. Cancer Inst. 86, 1159-1166.

SHURIN, M.R., ESCHE, C., PÉRON, J.-M., and LOTZE, M.T. (1997). Antitumor activities of IL-12 and mechanisms of action. Chem. Immunol. 68, 153-174.

SIDERS, W.M., Wright, P.W., HIXON, J.A., ALVORD, W.G., BACK, T.C., WILTROUT, R.H., and FENTON, R.G. (1998). T celland NK cell-independent inhibition of hepatic metastases by systemic administration of an IL-12-expressing recombinant adenovirus. J. Immunol. 160, 5465-5474.

SPEISER, D.E., MIRANDA, R., ZAKARIAN, A., BACHMANN, M.F., MCKALL-FAIENZA, K., ODERMATT, B., HANAHAN, D., ZINKERNAGEL, R.M., and OHASHI, P.S. (1997). Self antigens expressed by solid tumors do not efficiently stimulate naive or activated $\mathrm{T}$ cells: Implication for immunotherapy. J. Exp. Med. 186, 645-653.

TANnENBAUM, C.S., TUBbS, R., ARMSTrong, D., FINKE, J.H., BUKOWSKI, R.M., and HAMILTON, T.A. (1998). The CXC chemokines IP-10 and Mig are necessary for IL-12-mediated regression of the mouse RENCA tumor. J. Immunol. 161, 927932.

TODA, M., MARTUZA, R.L., KOJIMA, H., and RABKIN, S.D. (1998). In situ cancer vaccination: An IL-12 defective vector/replication-compete nt herpes simplex virus combination induces local and systemic antitumor activity. J. Immunol. 160, 4457-4464.

TOPALIAN, S. (1994). MHC class II restricted tumor antigens and the role of $\mathrm{CD} 4+\mathrm{T}$ cells in cancer immunotherapy. Curr. Opin. Immunol. 6, 741-745.

TRINCHIERI, G. (1998). Interleukin-12: A cytokine at the interface of inflammation and immunity. Adv. Immunol. 70, 83-243.

VAN den EYNDE, B., LETHÉ, B., VAL PEL, A., DE PLAEN, E., and BOON, T. (1991). The gene coding for a major tumor rejection antigen of tumor P815 is identical to the normal gene of syngeneic DBA/2 mice. J. Exp. Med. 173, 1373-1384.

WICK, M., DUBEY, P., KOEPPEN, H., SIEGEL, C.T., FIELDS, P.E., 
CHEN, L., BLUESTONE, J.A., and SCHREIBER, H. (1997). Antigenic cancer cells grow progressively in immune hosts without evidence for $\mathrm{T}$ cell exhaustion or systemic anergy. J. Exp. Med. 186, 229-238.

YEE, C., RIDDELL, S.R., and GREENBERG, P.D. (1997). Prospects for adoptive $\mathrm{T}$ cell therapy. Curr. Opin. Immunol. 9, 702-708.

ZILOCCHI, C., STOPPACCIARO, A., CHIODONI, C., PARENZA, M., TERRAZZINI, N., and COLOMBO, M.P. (1998). Interferon $\gamma$ independent rejection of interleukin 12-transduced carcinoma cells requires $\mathrm{CD} 4+\mathrm{T}$ cells and granulocyte/macrophage colony-stimulating factor. J. Exp. Med. 188, 133-143.
Address reprint requests to: Dr. Ignacio Melero or Dr. Cheng Qian

Facultad de Medicina Universidad de Navarra C/Irunlarrea, 1 31008 Pamplona, Spain

E-mail: imelero@unav.es

Received for publication April 21, 1999; accepted after revision October 19, 1999. 